\title{
Film/History/Experience
}

Histospheres model historical worlds that spectators are able not merely to audiovisually perceive, but also to physically and sensuously live. This chapter describes the interactions and intersections between film experience and historical experience. In the first section, I introduce the phenomenological theories underpinning the notion of film experience and apply them to the historical film, focusing on concepts of embodied film perception in which spectators have an impression of making direct contact with a film's historical world. This imaginary contact with history bears similarities to Frank R. Ankersmit's theory of historical experience, which I examine in the second section. ${ }^{1}$ The interconnections between Ankersmit's concept of historical experience and Vivian Sobchack's phenomenological theory of film experience ${ }^{2}$ are considered in greater depth in the third section, and related to other theories of film and history. The aim is to synthesize existing theories and develop a concept of histospheres in which sensuous and cognitive perceptions are fused into a unified cinematic experience of history.

\section{Phenomenology of Film}

The fear of injury and death, the deep water of the river, and the dramatic music at the start of SKY WITHOUT STARS. Trees and a jetty, the peaceful tweeting of birds, and the calm voice of the narrator in YEARS OF HUNGER. Joy and excited anticipation, dancing and cheering in the first few minutes

(C) The Author(s) 2021

R. Greiner, Cinematic Histospheres, https://doi.org/10.1007/978-3-030-70590-9_4 
of KU'DAMM 56. We feel the histosphere before we understand it; it is intuitively experienceable. If we wish to analyze this form of film experience more closely, a phenomenological methodology lends itself especially well. Although constructivist and semiological methods of film analysis can explain how audiovisual processes can model a historical space-time structure, they cannot wholly make sense of how we are able to intuitively experience a histosphere. The existential phenomenology of the philosopher Maurice Merleau-Ponty, as applied to film by Vivian Sobchack, provides an explanatory model based on the interrelationship between the living body and the lived world. ${ }^{3}$ Viewed through this phenomenological lens, the figuration of historical worlds in historical films appears in a new light.

The film scholar Thomas Morsch describes the concept of embodied perception central to Sobchack's phenomenological theory as follows:

Film not only makes a world visible, but also a perspective on this world. It is the only medium to afford access to something that otherwise remains barred to us: the embodied perception of someone other than ourselves. Anyone can see that someone else is also seeing something, but we cannot see this seeing itself. ${ }^{4}$

Sobchack herself writes:

A film is an act of seeing that makes itself seen, an act of hearing that makes itself heard, an act of physical and reflective movement that makes itself reflexively felt and understood. ${ }^{5}$

She posits two levels of perception: The primary structures of a film are founded in conscious experience and constituted as systematic communicative competence, while the secondary structures generate systematic distortion constituted as ideology, rhetoric, and poetics. ${ }^{6}$ Sobchack's theory complements conventional methods of film analysis by offering an alternative approach. Instead of abstracting the "wild meaning" of a film into discrete codes, she argues that the film "makes sense by virtue of its very ontology." The sensuous and meaningful expression of experience becomes an experience for the spectator in its own right.

On Sobchack's account, methods of constructivist analysis that dissect films down into their individual components do not merely simplify but distort; they reduce films to their production, structure, and aesthetics, so 
as to make them describable by theory. Phenomenology, by contrast, describes perception as a holistic experience that elicits a multilayered, prereflective impression. The histosphere model is based on a similar notion of holistically experiencing a world. The river, the escape from the guards, and the sound of gunshots in SKY WITHOUT STARs; the tranquil lakeside idyll in YEARS OF HUNGER; the dynamic dancing and rhythm of the music in KU'DAMM 56: Audiovision and movement form an elementary experience that precedes and inaugurates the secondary, more abstract meanings. ${ }^{8}$ The audiovisual figurations thus prefigure the historical significance of the histosphere, which is only manifested as such in the process of reception-whether in the guise of the families torn apart by German division in SKY WITHOUT STARS, the day-to-day life of a lower-middle-class family in the Wirtschaftswunder period in YEARS OF HUNGER, or a young woman's struggle to shape her own destiny in KU'DAMM 56. Histospheres have their origins in sensory perception: a point anticipated by Siegfried Kracauer, who wrote that "unlike the other types of pictures, film images affect primarily the spectator's senses, engaging him physiologically before he is in a position to respond intellectually." $\mathrm{A}$ phenomenological approach to film builds on this recognition. While Sobchack describes embodied perception as the aesthetic core of the medium, Steven Shaviro bases his theory of the "cinematic body" on the spectator's perceiving body, which undergoes a genuine sensuous experience in the movie theater. ${ }^{10}$ Both approaches can be understood as part of a paradigm shift "connected to the establishment of the body as a focus of interest in film theory."11 Sense and meaning, Thomas Morsch explains, are inherent in the sensuous material rather than being added to the embodied perception at a later stage by "intellectual transformation." 12 Following MerleauPonty's phenomenological theories, Morsch argues that "the corporality of the spectator should be understood as a productive power of aesthetic experience." 13 The somatic constitutes "a form of experience that is already meaningful in itself," a "fleshly understanding" that cannot be replaced by a cognitive notion of understanding. ${ }^{14}$ The film as embodied perception does not simply evoke affective somatic responses such as desire and disgust, but uses our body "as the 'universal medium' in which perception occurs and through which experience and meaning are mediated." 15 Accordingly, a key aspect of film experience consists in "embodied understanding of cinematic materiality." 16 Film as embodied perception thus refers to our day-to-day perception of the world, but differs from it materially. This difference is discernible in particular in the haptic, olfactory, 
and gustatory qualities of the filmic world, which are disclosed only through the indirect (and unconscious) route of our synesthetic perception of film image and film sound.

Proceeding from this premise, Sobchack's phenomenology of film is based around a dual structure of seeing and being seen. ${ }^{17} \mathrm{~A}$ film itself "sees" a world of visible images. As spectators, we simultaneously perceive these film images as a filmic world and as an intentional perspective on this world. ${ }^{18}$ The film constructs, as Morsch puts it,

a visible visual relation between an embodied eye and the sensuous world, and mediates this relation in the form of cinematic expression as an experience for the spectator. ${ }^{19}$

However, he argues, the intentionality of the film and that of the spectator are not identical; the film's perceptive activity is understood as being like mine but not as mine. ${ }^{20}$ Both Morsch and Anke Zechner support this distinction with a comparison between film and photography: Film not only makes an object and a perspective on it visible, but expresses this relation in a way that, according to Morsch, determines "its specific communicative character and aesthetic structure." ${ }^{21}$ Zechner observes that film, by contrast with the fixed, representing photographic picture, is not perceived as an object "but as the experience of world by an anonymous intentional subject that "pictures to themselves a representation [sich eine Darstellung vorstellt] of the objective world." 22 This point can be illustrated by the example of the soldier's portrait hanging in Anna's parentsin-law's home early on in SKY WITHOUT STARs. What enables a historical experience here is not the photograph as a historical source showing a soldier from the Second World War, but the film's perception, its intentional gaze, which here coincides with the gaze of the main character. We see not just the purportedly historical photograph but also the film's perspective on the process of coming to terms with the war that was underway in the mid-1950s. The picture also points to something else: Classical film theory describes a productive relationship between cadre and cache, where the aesthetically framed moving image creates a relative off-screen space. Sobchack distinguishes here once again between the gaze of the film and the gaze of the spectator: The film image may appear to us like a geometric window in the darkness through which we can perceive a world, but no boundaries of image exist for the gaze of the film itself. ${ }^{23}$ The film peers upon an unlimited, internally consistent world. The more we make 
the film's perception our own, the more the frame will blur until it dissolves entirely into the horizons of an open world.

Sobchack also refers to the joint act of seeing by film and spectator that underlies every film experience as the "address of the eye," ${ }^{24}$ which implies an embodied, situated mode of being and a material world that can only be perceived if the seeing and visible subject has its own body. The film's body has similar sensory capacities to that of the spectator. ${ }^{25}$ Just as the human body cannot be reduced to its physiological and anatomical features, nor can the film's body be reduced solely to discrete technical mechanisms; rather, it is part of a complex phenomenology. ${ }^{26}$ We can intentionally live through and physically experience the film's incarnate vision as if we were perceiving information from our own body. ${ }^{27}$ But even if the film's perception largely accords with our own, we are, as Sobchack emphasizes, fully aware while watching the film that we are living through another subject's perception as part of our own perceptual experience. ${ }^{28}$ In terms of the histosphere model, this would mean that the film sensuously perceives the simulated historical world and thereby makes this world sensuously available to the spectator. It does so by evoking the impression of being materially connected to the historical world. Although Sobchack describes the film's body as being invisible and genderless, ${ }^{29}$ it nonetheless has a physical presence that is expressed in audiovisual actions, a particular stance, and an intentional style ${ }^{30}$ Conversely, the audiovisual processes that structure the histosphere mold the presence of the film's body into a historical body. If, when watching a historical film, a diffuse sense of historicity sets in, this is attributable not just to the historical world that the film presents to us but also to our visceral connection to the film's perceiving body. The embodied cinematic subject does not simply convey the perceptual impression of a being-in-the-world, but is itself shaped by the audiovisual processes that model the perceived historical world. The film's perception of world is also highly subjective. A film always also tells a personal story, which the medium itself inscribes with a subjectivized historicity. As Sobchack puts it, film experience allows us to explore a world in the mode of an "autobiography" writing itself. ${ }^{31}$ In our presence we live the film's perception "as a visual, kinetic, and gestural discourse, as the immediate and direct enunciation of its own present engagement with the world enabled by a bodily presence in it." 32 The historical world modeled as a histosphere becomes experienceable as the perception of another through whose eyes we see and through whose ears 
we hear. This allows the spectator to identify closely not just with the film's characters but also with the cinematic subject and body.

Sobchack's phenomenology of film can also help give us a better grasp of the temporal aspect of histospheres. The present moment of a film's perception is linked to the time of its production by technical and stylistic traces. In SKY WITHOUT STARs, we live through the early 1950s on the perceptual foundation of a cinematic body from almost the same time. In YEARS OF HUNGER, by contrast, the representation and perception are based on a cinematic body from the 1980s, while KU'DAMM 56's cinematic body dates from the 2010s. Cultural and political factors and developments in film design and technology can affect our individual perceptions and thereby also the form of the film's body. As spectators, we do not need to consciously assume the perspective of a subject from the time that the film was made; rather, we prereflectively adopt the specific perception of the contemporary cinematic subject. At the same time, what is visible to the film and the spectator as "images" is always the result of a process of selection. Within the context of a certain culture and history, the film selects which parts of the filmic world will become visible and which will remain invisible. ${ }^{33}$ What we see has already been organized and structured by our vision and that of the film in a way that reflects a particular intention toward the world. ${ }^{34}$ The histospheres in SKY WITHOUT STARS, YEARS OF HUNGER, and KU'DAMM 56 are not simply a representation or recreation of a bygone era; the historicity of the film's body is manifested in the film's perspective on the audiovisual figurations, and is thus also inscribed in our film experience.

\section{Historical Experience}

The sequence in SKY WITHOUT STARS in which Anna stares at the portrait of the soldier in her parents-in-law's home can help give us an initial sense of what is meant by historical experience. The protagonist is shocked by the presence of the photograph, and pauses for a moment. Although the way the scene is staged suggests that this is primarily a response to the violent loss of her husband, the sequence also depicts a phenomenon that the philosopher of history Frank R. Ankersmit describes as "authentic contact" with the past. ${ }^{35}$ For Anna, the photo blurs the boundary between aesthetic and historical experience, and her present moment comes into contact with another, earlier layer of time. The kind of phenomenon that 
is here presented as an effect of trauma can also, I argue, be triggered by our perception of a film.

The topic of experience has attracted growing attention in both film and historical studies since the early 1990s. In both cases, this is at least in part a reaction to the linguistic turn, with a physical-sensory, prenarrative concept of experience serving to counteract an "overemphasis on the autonomy of the linguistic constitution of objects and production of meaning." 36 This represents a return to history's original conception of itself as a science of experience. ${ }^{37}$ Nonetheless, there do still remain some points of connection with language that cannot be neglected. Although Ankersmit claims that narrativism is fundamentally antagonistic to historical experience, ${ }^{38}$ elsewhere he emphasizes language's potential to make backward inferences from narratives to prelinguistic experience. ${ }^{39}$ This apparent contradiction can be resolved by reference to the category of aesthetics. When Ankersmit speaks of how fragments of historical texts can give rise to a historical experience, he assumes a performative act, a living encounter with the historical textual artifact. The associated aesthetic experience goes beyond the potential of the symbolic linguistic code, and in many respects resembles the notion of historical experience mediated through film experience that I shall set out in subsequent chapters. ${ }^{40}$

While Jörn Rüsen defines historical experience as the "experience of difference [...] between one's own and the other time,"41 Ankersmit's conception goes further than this. His notion of historical experience centrally involves the surprising subjective impression of making direct contact with the past. Referring to the work of cultural historian Johan Huizinga, Ankersmit argues that this contact is always accompanied by "an absolute conviction of authenticity and truth." 42 Furthermore, he notes that for Huizinga even relatively unimportant objects can provoke historical experiences, ${ }^{43}$ a further point of difference from political history. Historical experience, in Ankersmit's view, dislodges a single aspect from the broader context of the past while simultaneously decontextualizing the historian's own existence. ${ }^{44}$ The willingness to sacrifice context on the side of both subject and object is "the condition for an intimate encounter between object and subject in a historical experience." ${ }^{45}$ Moreover, as a singular event, a historical experience cannot be repeated or evoked at will; "it 'overcomes' the historian and cannot be forced." 46 Ankersmit emphatically uses the term "surprise" to underline the sudden and unintended occurrence of historical experience, which he believes emanates from the power of an object. ${ }^{47}$ This gives an impression of its being "as if any 
temporal gap between today and the past had disappeared for a brief moment." 48 For Ankersmit, this "disappearance of temporal dimensions" 49 represents the most important feature of historical experience, the impression of direct and unmediated contact with the past. ${ }^{50} \mathrm{He}$ believes one way to explain this phenomenon lies in the "recognition that a historical experience, despite being stimulated by an object given to us in experience, at the same time [assumes] the character of a self-experience." ${ }^{51}$ Put another way: Assuming an impression of authenticity, a historical experience allows us to become aware not just of the world but also of our own self. Taking the example of apparent perspectival inconsistencies in a painting by Francesco Guardi, Ankersmit develops the thesis that historical experience is characterized by an "improbable probability" that "is able to transform into probability not despite but precisely because of its improbability"; 52 it is precisely the artificial transformation of conventional visual experiences that evokes an impression of authenticity. This point will also prove significant in my discussion of the relation between historical and film experience.

The bodily dimension of historical experience represents one fundamental point of analogy to the phenomenology of film. Ankersmit notes that in the moment of this experience, the illusion is created that one can physically touch the past. ${ }^{53}$ Based on Aristotle's epistemology and MerleauPonty's concept of "tactile seeing," he assigns historical experience to the sense of touch. ${ }^{54}$ By this he means not just haptic perception of the physical world, but also a simultaneously occurring form of self-experience. ${ }^{55}$ According to Ankersmit, in historical experience "tactile seeing" makes not just the past but also our own embodied existence palpable ${ }^{56}$; the sense of touch is characterized by immediacy, experience through selfexperience, and contiguity of object and subject. ${ }^{57} \mathrm{He}$ assigns different human senses to different modes of access to history: Historical experience is like "being touched by the past," ${ }^{58}$ whereas historical texts seek to control and structure the past, for which reason Ankersmit associates them with the metaphor of seeing. ${ }^{59}$ Historical debate, meanwhile, attests to the relativity of all historical insight and is therefore connected to the metaphor of hearing. ${ }^{60}$ These classifications make clear that Ankersmit does not wish to pit historical texts and debate against historical experience. ${ }^{61}$ Rather, the metaphorical schema in which different forms of history are associated with different senses is used to describe a complex process of mutual exchange. Historical insight is produced synesthetically in the mode of self-experience. ${ }^{62}$ We can see here a point of connection with the medium of film, which likewise combines the senses of seeing and hearing to create worlds that can be physically experienced by the spectator. 
Subsequent work has both criticized and built on Ankersmit's theory. In one study by Thiemo Breyer and Daniel Creutz examining the relationship between experience and meaning, they suggest that it is narrative that "configures the meanings of the sensory structures inherent in historical experience." ${ }^{\prime 3}$ Consequently, they criticize Ankersmit's theory for semantically narrowing the actively exploratory sense of experience (Erfahrung) to a passive, receptive one (Erlebnis). ${ }^{64}$ For Breyer and Creutz, experience always also involves taking a stance, always has an inherent self-reflective aspect. ${ }^{65}$ However, one problem with their account is that they discuss historical experience solely in instrumental terms, where the function of historical experience is to produce meaning. ${ }^{66}$ They are thus largely unreceptive to Ankersmit's concept of physical-sensory experience. The assumption that experience can in principle be narrated instead leads them to an expanded conception of narrative based on its "structuring function in terms of temporality, relevance, and belonging to a configured unit of representation." 67 The core of this conception is a multilayered model of historical experience comprising short-term eventful moments, experiential contents that become habitual/socialized over the medium term, and ones that are biologically/anthropologically formed over the longer term. ${ }^{68}$ However, although the remainder of Breyer and Creutz's study concentrates primarily on historical narratives and the historical experiences evoked by them, their ideas can nonetheless also be productively applied to fiction films, which address spectators both sensuously-aesthetically and narratively. ${ }^{69}$

\section{Film Experience And History}

The epistemological paradigm shift from modernism to postmodernism in the 1980s paved the way to address the subjectivation of historical processes. ${ }^{70}$ Bernhard Groß believes that the relation between the individual and history is nowadays inextricably bound up with the understanding of film that developed after $1945 .^{71}$ In the postwar period, Hollywood cinema has become one mode of adequate experience of the modern lifeworld: "Popular genre cinema could become emblematic of the idea of a new society founded on egalitarian democracy," summarizes film scholar Hermann Kappelhoff; "the cinema audience no longer functions as the representative of a new collective way of existing, but is addressed as [...] a gathering of anonymous individuals." 72 A phenomenological approach to film responds to this process of democratization and individualization and understands the film image in terms of a "physical-sensory 
being-in-the-world."73 On this foundation, histospheres offer a view of historical worlds from the inside. The status of historical films and their makers as amateur historians as postulated by Simon Rothöhler ${ }^{74}$ can, consequently, be expanded to film spectators too. Furthermore, film functions as an externalized process of individual (as opposed to cultural) memory. ${ }^{75}$ Expanding on this idea in phenomenological terms, the individual experience of history develops not just through the externalization of the process of remembering into film, but also through its embodied reappropriation in the process of film experience.

The ending of SKY WITHOUT STARs shows that film and historical experience are underpinned by a similar principle: When the expansion of border fortifications means it is no longer safe to meet at the abandoned train station in no man's land, Anna and Carl decide to flee to the West with Anna's grandparents. But the plan goes awry. The East German border guards shoot Carl, while Anna is hit by a bullet when the West German border police return fire. As the patrol dogs wage a bloody proxy war, the dead lovers lie side by side, their hands almost touching (Figs. 4.1, 4.2, 4.3, and 4.4). However, it is not the sight of the corpses but the starkly lit,

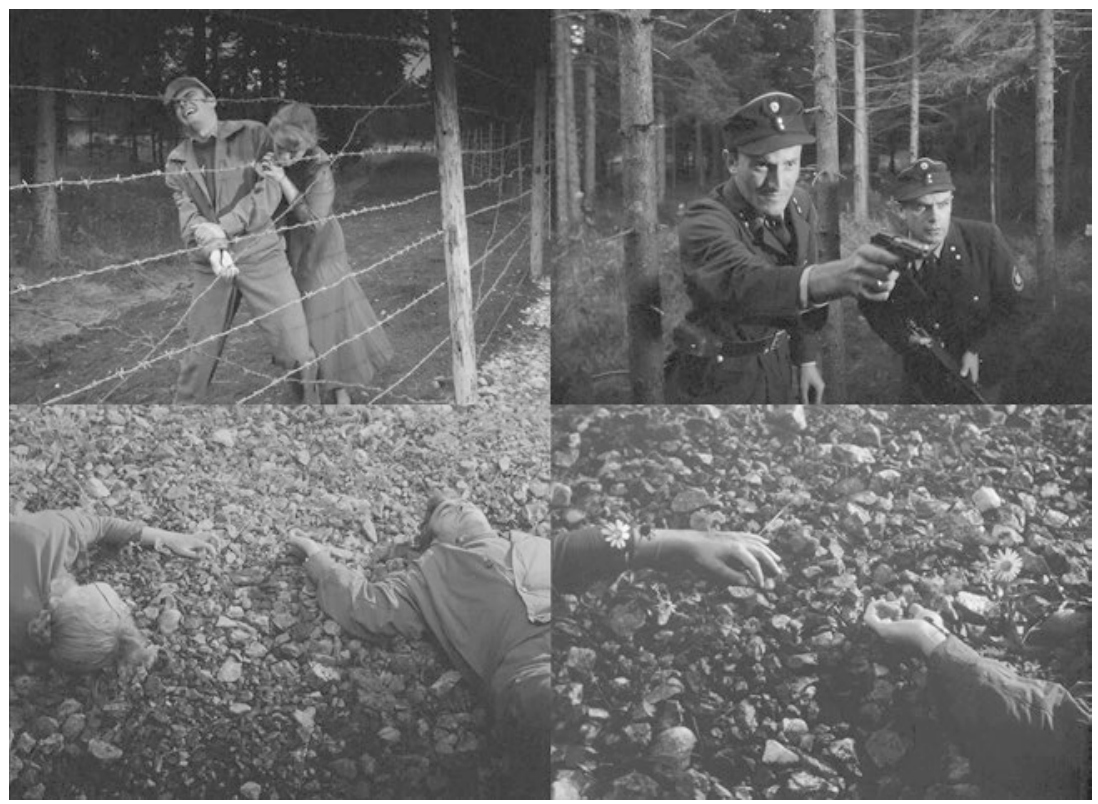

Figs. 4.1-4.4 The death sequence in SKY wITHOUT STARs 
almost three-dimensional-seeming gravel on which they lie that creates a vivid moment of shock. The sensuous experience it evokes is strikingly close to Anke Zechner's description of a sequence from Michelangelo Antonioni's THE ECLIPSE (1962):

Our perception is directed to the surface textures, and connected to memory via subjective inner time. Associations emerge directly out of our memory. We get "flashes" of disconcertment, but also of similarity. ${ }^{76}$

Walter Benjamin often wrote of such momentary "flashes" of recognition. ${ }^{77}$ With regards to the "aesthetics of shock $[\ldots]$ in film reception," 78 Benjamin gives an interesting analogy between film perception and historical knowledge that he does not elaborate on further: The past can only be held fast as it whizzes by, "only as a picture, which flashes its final farewell in the moment of its recognizability." "79 A moment of shock halts thought and produces a dialectical picture; a monad in which our whole conception of the world is reflected ${ }^{80}$ Christa Blümlinger concludes from this that

Following Walter Benjamin (and contrary to his reservations about film as mass art), it can be maintained that no art can historically articulate the past in the way cinema can, for inherent in the transience of the film image is a specific possibility of experience and thought. ${ }^{81}$

Walter Benjamin's concept of shock has some important parallels to Ankersmit's concept of “surprise." 82 For instance, Ankersmit's (Aristotelian) view that we must "suffer" the moment of historical experience corresponds to Benjamin's thesis that shock can overwhelm our mental defenses and have a traumatic effect. ${ }^{83}$ This thesis can also be transposed to the aesthetics of shock in film reception; a point that is especially relevant to historical experience in historical films is that "to articulate what is past does not mean to recognize 'how it really was.' It means to take control of a memory, as it flashes in a moment of danger." 84 Consequently, we can posit a conceptual similarity between film and historical experience. A special role is played by the incomplete representation of reality in film. The two-dimensional film image in SKY WITHOUT STARS merely simulates the spatiality of the depicted world and douses it in shades of gray. The sound is rather tinny and dull. While film theorists like Rudolf Arnheim claim that the more limited a film's means for realistic representation, the greater its artistic effect, ${ }^{85}$ artificiality has the opposite 
consequence for historical experience. "It can't be so!" flashes through our head-and yet "It must be so." ${ }^{86}$ Just as in Ankersmit's theory, in film too historical experience is characterized by its coming to seem probable not despite but precisely because of its improbability. ${ }^{87}$ The technical and aesthetic limitations in the representation of the historical world are perceived as a valid expression of historical authenticity. It is no longer the filmmakers, during the production of the film, who judge what is authentic, but the spectators, in the process of watching the film. "The authentic contact with the world always has something paradoxical about it, an incompleteness, defect, or awkwardness," Ankersmit continues. ${ }^{88}$ Historical films take advantage of this fact. Since the early 1990s, there has been a tendency for films to deliberately simulate older films' technically limited aesthetic devices and aging-related defects in order to create an impression of authenticity and label the audiovisually configured world as historical. Benjamin's mirror metaphor also plays an important role in theories of the relation between cinema and history. For instance, Kracauer describes the film image as a mirror that makes the horrors of historical reality bearable and so allows us to experience them..$^{89}$ This point is also illustrated in the final sequence of SKY WITHOUT STARs. It is only the "physical reality" $" 90$ of the stony ground, which we can link back to our own experiences of reality, that allows us to grasp the violent death in all its senselessness. The associative chain can also be expanded by Michel Foucault's notion of heterotopia, which in the mirror of the film image is connected to utopia. ${ }^{91}$ The heterotopic other place, the past, blends with an unreal, utopian cinematic space. This provides the basis for reflecting on the fate of this unfortunate couple and understanding it as a metaphor for divided Germany. The small, affecting moment draws our attention to the big picture. A histosphere is both things at once: utopia and heterotopia, experience of history and shocking self-experience.

To better understand the connection between film perception and historical experience, it will be helpful to return to Sobchack's phenomenological theory. Sobchack understands film as a communication system that uses sensuous experience to make meaning visible, audible, and tangible; ${ }^{92}$ film is able to deliberately simulate and model historical experience. This view is supported by Breyer and Creutz's thesis of a mediating intersubjective dimension "that makes it possible to understand the experiences of others or imaginatively transform one's own experiences." 93 Film experience functions very similarly: It is not just based on our own perceptions and reflections on them, but also allows us to perceive and reflect on the 
experience of the cinematic subject. ${ }^{94} \mathrm{~A}$ histosphere thus makes historical experience available in two senses: Firstly, we have the impression of making direct contact with the past ourselves; secondly, we can apprehend the perception of the cinematic subject, which is sometimes more, sometimes less closely connected to the perception of a film character. The portrait of the soldier in SKY WITHOUT STARS connects both the diegetic present of the protagonist Anna and the present of the film spectator to an earlier period of time. The rumble of the engine, which is almost physically palpable for the spectator, and the shaking of the apartment evoke associations with the wartime air raids. These associations function on two levels: Firstly, they create connections to earlier (film) experiences on the part of the spectator; secondly, they reflect the experience the film character is depicted as having in this moment.

If we take plot into account when considering the relation between film experience and historical experience, more general questions of narrative theory will also come into focus. For historian Jörn Rüsen, the basis for historical experience resides in the fact that the past is always already there, not as history "but as absolute presence, just as the pasts of a tree trunk (spread over the years) are there in its rings in the here-and-now." 95 According to Rüsen, this prenarrative simultaneity of past and present is transformed only at a later stage, when it is worked into a chronological narrative. ${ }^{96}$ Historical films function in a very similar manner: By stimulating the spectator's senses, they activate a chain of prenarrative associations already present in the spectator's memory, so that the past becomes an experience in the present. Although film makes use of narrative elements to help produce the historical experience, the spectator's perception plays out in the "anteroom of history" 97 and is only subsequently transformed into conceptual thought, and then into a historical narrative. The introductory voice-over in YEARS OF HUNGER describes a similar process, albeit in terms of trauma and repression, highlighting the importance of conscious remembering for the historiographic process.

I had tried to forget-for years on end. I remembered cities, houses, places, other people. But I had expunged myself from my memories. I constantly invented new goals so that I always had to look forward. If I came too close to myself, I escaped into hectic work-or debilitating illness. I was thirty by the time I realized the past wouldn't let me go. I was living with a petrified heart that was still thirteen years old. And I forced myself to remember. That summer .... 
Despite the autobiographical nature of the voice-over, the narrator's words also have more general import. This appears to be another case where Rüsen's theory can fruitfully be applied to the medium of film; for instance, his observation that the past already exists in the memory "as moment, as image, as gesture, as idea" even before it has been made present through narrative. ${ }^{98}$ I believe this "memory content" ematic forms of representation not just in its conceptual content but also in its "peculiar momentariness." 100 "The film is always happening now,"101 maintains documentary maker Johan van der Keuken, true to the pioneering theories of Kracauer and Balázs, who are never tired of emphasizing the momentary character of cinema. ${ }^{102}$ In historical experience, the film's now is combined with a retrospective narrativization of history. Consequently, historical experience can no longer be separated from (hi) storytelling, since in the moment of its inception it is fused with the prenarrative associations and recollections of the experiencing subject. The fictional narrative of a historical film adds an additional layer to this process. Breyer and Creutz rightly point out

that stories have the power to convey other people's experiences to us and allow us to imaginatively "relive" them, such that by using imagination and empathy we are able, from the perspective of the narrator or characters, to relate to their experience as if we ourselves were having it right now. ${ }^{103}$

Breyer and Creutz argue that although this as-if experience is to be distinguished from the actual experience of historical figures, it could itself become an actual experience for the spectator, especially "if they themselves did not actually experience [erleben] what they are reliving and so it does not form part of their own store of experience." 104 The same happens in film: In the moment of historical experience, the film experience, which according to Sobchack is direct and embodied, blends not just with the spectator's cognitive associations, but also with the perceptions of the film's body and with the film's historical narrative. However, the specific form this sudden surprise "by the power of the object" 105 takes in film requires further elucidation. At certain points in a historical film, the boundaries between the film's embodied perception and that of the spectator, between prenarrative and narrative layers, and between film experience and historical experience are ruptured.

In the remainder of this chapter, I shall attempt to connect this phenomenon to the concepts of studium and punctum developed by Barthes 
in his theory of photography. ${ }^{106}$ Barthes defines studium as "application to a thing, taste for someone, a kind of general, enthusiastic commitment, of course, but without special acuity." 107 This interest is always bound to a particular context, whether one in which photographs are categorized as "political testimony" or one where they are seen as "good historical scenes." 108 Barthes suggests here a concrete connection to history that the studium allows the spectator to participate in; the punctum, by contrast, breaks through the studium:

This time it is not I who seek it out (as I invest the field of the studium with my sovereign consciousness), it is this element which rises from the scene, shoots out of it like an arrow, and pierces me. ${ }^{109}$

To explain the significance of punctum for photography, Barthes draws an analogy to the medium of film. He uses the film theory category of cache as a metaphor for a "blind field," a relative off-screen space, that extends beyond the frame and in which the depicted world continues beyond what is visible in the image or on the screen. ${ }^{110}$ Through the punctum, we gain imaginary access to this place. We can also fruitfully apply this implicit connection between punctum and cinema to an analysis of the relation between film and historical experience, and its applicability is by no means limited to the visual level. In the opening sequence of YEARS OF HUNGER, the voice-over switches without warning from the adult Ursula to a much younger speaker. With a soft, surprisingly deep voice, the young Ursula reads with feeling from a book:

And when he went out into the world, he found many wonderful things just waiting to be discovered. Cashmere scarves embroidered with golden flowers, as fine as spiderwebs, carved ivory chests filled with Russian tea, an old violin with a picture on the back ...

Barthes describes the punctum of a photograph as "that accident which pricks me"; as a "detail" that "changes my reading." 111 Both these descriptions apply to Ursula's voice in the opening sequence of YEARS OF HUNGER. The change of voice "pricks" us at a sensuous level while also pointing beyond what is represented in the sound and images. This demonstrates that there is indeed potential to extend the concepts of studium and punctum from photography to historical films. ${ }^{112}$ If the studium, as Barthes claims, is "always coded," "113 then it would make sense to categorize it as a 
constructivist-analytical approach to the histosphere, making it an apt mode for perceiving the cinematically modeled figuration of a historical world. Barthes's hypothesis that the studium is based on a communicative pact "between creators and consumers" 114 also reveals parallels to certain fundamental parameters of genre studies. For Francesco Casetti, film genres function as "complex negotiating machines" whose purpose is "to solve the confrontation between film and viewer productively." "115 Analogously, a histosphere produces filmic signs that can be decoded by means of the studium. The punctum, by contrast, pierces the production of semiotic meaning and adds a level of prenarrative, sensuous experience to the perception of a histosphere. Barthes's noema of photography, "thathas-been," 116 converges here with the improbable probability from Ankersmit's theory of historical experience. We know that the fiction film is only simulating the depicted history, and yet we feel differently: "It can't be so!', and yet 'It must be so."'l17 However, by contrast with Barthes, who admits to having conflated "truth and reality in a unique emotion" 118 under the effect of the punctum of a photograph, the historical experience that we have during a historical film remains fictional. While Barthes claims that the photograph leads us to believe that its referent had really existed, in the historical film this false inference is replaced by the presence of the histosphere. The historical film becomes a form of historical experience, in a manner very similar to Balázs's description of the effect of "absolute film":

What matters $[\ldots]$ is merely the optical impression, not the reality represented. Objects lose their substance here because what the films value is appearance. The image itself is the reality that is experienced. ${ }^{119}$

It is this potential that gives historical films their unique intuitive persuasiveness; what matters most is not how factually accurate a film is, but how intuitively believable its aesthetic design is. My hypothesis is that no study of popular conceptions of history would nowadays be complete without considering the intermeshing of aesthetic and historical experience. The following chapters will therefore not simply examine how histospheres model or referentialize historical worlds, but will focus in particular on how they make history sensuously available as lived reality. 


\section{Notes}

1. See Frank R. Ankersmit, Die historische Erfahrung, Berlin 2012, p. 19.

2. See Vivian Sobchack, The Address of the Eye: A Phenomenology of Film Experience, Princeton 1992.

3. Sobchack notes that Merleau-Ponty describes the interrelationship between living body and lived world with the term être-au-monde, which combines a being-present-to-the-world with a being-alive-in-the-world. Ibid., p. 38.

4. Thomas Morsch, "Filmische Erfahrung im Spannungsfeld zwischen Körper, Sinnlichkeit und Ästhetik," montage AV 19:1, 2010, p. 58.

5. Sobchack (1992, pp. 3-4).

6. Ibid., p. 8.

7. Ibid., p. 12.

8. Ibid.

9. Siegfried Kracauer, Theory of Film: The Redemption of Physical Reality, Princeton 1997, p. 158.

10. Steven Shaviro, The Cinematic Body, Minneapolis 1993. See also Thomas Morsch, Medienästhetik des Films: Verkörperte Wahrnehmung und ästhetische Erfahrung im Kino, Munich and Paderborn 2011, pp. 174, 186.

11. Ibid., p. 7.

12. Ibid., p. 168.

13. Ibid., p. 170.

14. Ibid., p. 173.

15. Ibid., p. 170.

16. Ibid., p. 173.

17. The term "seeing" should be understood here as synonymous with the film's perception, which also includes hearing.

18. Sobchack (1992, p. 56). Niklas Luhmann's concept of "second-order observation," the observation of observations, can also be applied here. Luhmann correctly observes that, in the case of art, "we may decide to observe a work of art solely in view of its intrinsic observations without observing the artist; it is enough to know or to recognize that we are dealing with artificial, rather than a natural, object." Niklas Luhmann, Art as a Social System, Stanford 2000, p. 56. What this entails for a theory of histospheres is that a film's intentional gaze should not be conflated with the intentional gaze of the filmmakers.

19. Morsch (2011, pp. 183-184).

20. Ibid., p. 178.

21. Ibid.

22. Anke Zechner, Die Sinne im Kino: Eine Theorie der Filmwahrnehmung, Frankfurt 2013, p. 49. 
23. Sobchack (1992, p. 131).

24. Ibid., p. 23.

25. Sobchack draws parallels between the development of cinema and the development of a human being: Analogously to the genesis of camera movement, an infant develops the ability to control the movement of its head and gaze even before learning to speak or walk. See ibid., p. 253.

26. Ibid., p. 169.

27. Ibid., pp. 138-140.

28. Ibid.

29. Ibid., p. 162. Sobchack describes the film's body as genderless and devoid of physical features (skin color, figure, age, etc.) However, this body's perception can certainly be marked by factors such as gender, class, and race. See on this point Katharina Lindner, "Questions of embodied difference: Film and queer phenomenology," NECSUS, autumn 2012: "Tangibility," https://necsus-ejms.org/questions-of-embodieddifference-film-and-queer-phenomenology/(last accessed May 1, 2020).

30. Ibid., pp. 133, 138.

31. Ibid., pp. 216-217.

32. Ibid.

33. According to Sobchack, seeing, as a particular mode of grasping and expressing a world, encompasses both the visible and the invisible, and does so always from the perspective of an embodied, situated, seeing subject, whether that be the filmmaker, the film, the spectator, or the film theorist. Ibid., pp. 287-288.

34. Ibid., p. 132.

35. Ankersmit (2012, p. 19).

36. Thiemo Breyer and Daniel Creutz, "Historische Erfahrung: Ein phänomenologisches Schichtenmodell," in Daniel Creutz (ed.), Erfahrung und Geschichte: Historische Sinnbildung im Pränarrativen, Berlin 2010 , p. 333.

37. For this reason, Breyer and Creutz speak of a "renaissance" or "revival" of the concept of experience, which has, they claim, never entirely disappeared from the discipline's self-conception but only temporarily been eclipsed by history's newfound "literary" status. Ibid.

38. Ankersmit $(2012$, p. 8).

39. Frank R. Ankersmit, "Sprache und historische Erfahrung," in Klaus E. Müller and Jörn Rüsen (eds.), Historische Sinnbildung: Problemstellungen, Zeitkonzepte, Wabrnehmungshorizonte, Darstellungsstrategien, Hamburg 1997, p. 388.

40. Ankersmit (ibid.) himself emphasizes the great similarity between aesthetic and historical experience. 
41. Jörn Rüsen, Historik: Theorie der Geschichtswissenschaft, Cologne 2013 , p. 38.

42. Ankersmit (2012, pp. 16-17).

43. Ibid., p. 17.

44. Ibid., pp. 17-18.

45. Ibid.

46. Ibid.

47. Ibid., pp. 20-21.

48. Ibid., p. 21.

49. On the parallels between historical experience and Kant's category of the sublime, Ankersmit writes: "Huizinga's and Meinecke's suggestion of explaining historical experience in terms of the 'disappearance of temporal dimensions' accords neatly with Kant's idea of the sublime, for the noumenal world to which the sublime affords access-recall Kant's example of the person awed by the monumental dimensions of St. Peter's Basilica-is a world not yet structured by the 'forms of intuition' [Anschaunngsformen] of space and time, and this 'disappearance of temporal dimensions' points in the same direction. [...] In both cases there is a surprising experience of a reality that presents itself with unprecedented directness and immediacy. In both cases the experience has the character of a suffering (pathos) of reality rather than a codification of it in terms of something already familiar, whether that be language, theory, discourse, Wirkungsgeschichte, categories of understanding, etc." Ibid., p. 56.

50. Ibid., p. 19.

51. Ankersmit describes the combination of self-experience and historical experience in the mode of authenticity as "contiguity," and sees in this another parallel to Kant's concept of the sublime. Ibid., p. 56.

52. Ibid., p. 43.

53. Ankersmit refers here to the work of Jo Tollebeek and Tom Verschaffel, who observe that historical experience makes the past "touchable and visible," and once again to Huizinga, who describes historical experience as "touching the essence of things." See ibid., p. 71; Jo Tollebeek and Tom Verschaffel, De vreugden van Houssaye: Apologie van de historische interesse, Amsterdam 1992, p. 18; Johan Huizinga, Verzamelde werken 2: Nederland, Haarlem 1950, p. 56.

54. Thus, "the directness and immediacy of historical experience of the past" is in accord "with the properties (described by Aristotle) of our way of experiencing reality through the sense of touch." See Ankersmit (2012, pp. 63-68); Aristotle, De Anima (On the Soul), London 1987; Maurice Merleau-Ponty, Le visible et l'invisible, Paris 1964, p. 173.

55. Ibid.

56. Ibid., p. 68. 
57. Ibid., p. 98.

58. Ibid., p. 74.

59. Ibid.

60. Ibid.

61. Ibid.

62. Ibid.

63. Breyer and Creutz (2010, pp. 334-335). Breyer and Creutz are, however, aware that experience is never entirely captured and absorbed by narrative, and conversely that the verbalization of experience has a surplus of categoriality. See ibid., p. 342.

64. Ibid., p. 349.

65. Ibid., p. 350.

66. See in particular their reference to Rüsen's theories. Ibid., pp. 339-340.

67. Ibid., p. 342. Breyer and Creutz do concede that not every form of experience prompts the same need for narration, nor can all experience be converted into narrative in the same way.

68. Breyer and Creutz define the three temporally differentiated levels of historical experience as follows: "(1) The characteristic qualities of having an experience [Erfahrung-Machen] at the first level (short term) are the novelty, singularity, irreversibility, unrepeatability, and surprisingness of the experience. (2) The second level (medium term) involves, in the sense of being experienced [Erfahrung-Haben/Erfahrenheit], experiential contents that are constituted in the process of socialization, in the adoption of cultural imperatives and experiential schemas handed down the generations, and in the habitualization of ways of thinking and acting, and that form the interpretive background for the events processed at the first level. (3) Finally, at the third level (long term), elements are incorporated into experience that transcend individual and generational constellations in the store of experience, relating on the one hand to human beings' basic biological and anthropological constitution and on the other to their naturally given environment, both of which can only be culturally transformed to a limited extent and extremely slowly." Ibid., p. 355.

69. While experiences relating to the content of plot/narrative can primarily be located at the first level (short term) of Breyer and Creutz's model, cinematic devices for representing history can be placed in the second level of experience (medium term). The authors' description of this level sounds almost like a description of genre conventions: "At the second experiential level, stocks of experience are deposited that involve consolidating repetition, 'medium-term stabilizations of experience,' and the accumulation of experiences that can mutually confirm or revise one another, and are thus likewise subject to (albeit rarely sudden) transformation that brings new experiential qualities with it.” Ibid., p. 356. 
70. See Bernhard Groß, Die Filme sind unter uns: Zur Geschichtlichkeit des frühen deutschen Nachkriegskinos: Trümmer-, Genre-, Dokumentarfilm, Berlin 2015, p. 58.

71. Ibid.

72. Hermann Kappelhoff, The Politics and Poetics of Cinematic Realism, New York 2015, p. 60.

73. Ibid., p. 64.

74. Simon Rothöhler locates the historical film outside the institutionalized discipline of history, and regards it as an innovative mode of access to history: "Knowledge generated outside institutions is the product of an unprofessional curiosity and of an epistemic mode that implicitly goes against official approaches, calls them into question, or in some cases even reveals them to stand in need of revision." Simon Rothöhler, Amateur der Weltgeschichte: Historiographische Praktiken im Kino der Gegenwart, Zurich 2011, p. 8.

75. See Groß $(2015$, p. 68$)$.

76. Zechner $(2013$, p. 15).

77. Walter Benjamin, "On the Concept of History," 2005, https://www. marxists.org/reference/archive/benjamin/1940/history.htm (last accessed May 1, 2020), thesis 5.Walter Benjamin, "On the Concept of History," 2005, https://www.marxists.org/reference/archive/benjamin/1940/history.htm (last accessed May 1, 2020), thesis 5 .

78. Andreas Jacke, Traumpassagen: Eine Filmtheorie mit Walter Benjamin, Würzburg 2013, p. 79.

79. Benjamin $(2005$, thesis 5$)$.

80. See Jacke (2013, p. 80); Benjamin (2005, thesis 17).

81. Christa Blümlinger, Kino aus zweiter Hand: Zur Ästhetik materieller Aneignung im Film und in der Medienkunst, Berlin 2009, p. 19.

82. Ankersmit (2012, pp. 20-21).

83. See Jacke $(2013$, p. 80$)$.

84. Benjamin (2005, thesis 6).

85. Rudolf Arnheim, Film as Art, Berkeley and Los Angeles 1957, p. 75.

86. Ankersmit (2012, p. 43).

87. Ibid.

88. Ibid.

89. Kracauer refers here to Greek mythology, in which Perseus uses the shield of Athena as a mirror in order to battle Medusa without looking at her directly. He understands the film image as an analogous tool that, following the same principle, makes it possible to face up to horrors such as the Holocaust. Kracauer (1997, p. 305). 
90. When he speaks of "physical reality," Kracauer is referring to a film's connection to a "pool of everyday phenomena" that it has "incorporated." See Sabine Nessel, Kino und Ereignis: Das Kinematografische zwischen Text und Körper, Berlin 2008, p. 48.

91. For Foucault, the mirror functions as the site of a "mixed, joint experience" where utopia and heterotopia coexist. See Michel Foucault, "Of Other Spaces: Utopias and Heterotopias," 1984, http://web.mit.edu/ allanmc/www/foucaultl.pdf (last accessed May 1, 2020), p. 4.

92. Sobchack (1992, p. 9).

93. Breyer and Creutz (2010, p. 346).

94. Sobchack (1992, p. 9).

95. Jörn Rüsen, Zerbrechende Zeit: Über den Sinn der Geschichte, Cologne 2001, p. 82 (hereinafter Rüsen 2001).

96. Ibid.

97. See on this point Kracauer's History, in which he repeatedly draws analogies between history and film. Siegfried Kracauer, History-the Last Things Before the Last, Princeton 1995. On the concept of the "anteroom" (Vorraum) of history, see Stephanie Baumann, Im Vorraum der Geschichte: Siegfried Kracauers History: The Last Things Before the Last, Konstanz 2014.

98. Rüsen (2001, p. 85).

99. Ibid.

100. Ibid.

101. In his film VAKANTIE VAN DE FILMER (The Filmmaker's Holiday, 1974) Johan van der Keuken draws the following contrast between film and photography: “The photograph is a memory. I remember what I'm now seeing. But the film doesn't remember anything. The film is always happening now."

102. See Kracauer (1997, p. 303$)$.

103. Breyer and Creutz (2010, pp. 345-346).

104. Ibid.

105. Ankersmit (2012, pp. 20-21).

106. On the concept of punctum, see Roland Barthes, Camera Lucida: Reflections on Photography, New York 1981, pp. 26-27 and 40-60.

107. Ibid., p. 26.

108. Ibid.

109. Ibid.

110. Ibid., p. 57.

111. Ibid., pp. 27, 42. 
112. Although Barthes himself distinguishes between film and photography, he admits to being ultimately unable to keep the two mediums separate. Ibid., p. 3.

113. Ibid., p. 51.

114. Ibid., p. 28.

115. Francesco Casetti, Communicative Negotiation in Cinema and Television, Milan 2002, p. 31.

116. Barthes (1981, p. 77).

117. Ankersmit $(2012$, p. 43$)$.

118. Barthes (1981, p. 77).

119. Béla Balázs, The Spirit of Film, in Béla Balázs: Early Film Theory, New York and Oxford 2010, p. 160.

\section{BIBLIOGRAPHY}

Frank R. Ankersmit, Die historische Erfahrung, Berlin 2012.

Frank R. Ankersmit, "Sprache und historische Erfahrung," in Klaus E. Müller and Jörn Rüsen (eds.), Historische Sinnbildung: Problemstellungen, Zeitkonzepte, Wahrnehmungshorizonte, Darstellungsstrategien, Hamburg 1997, pp. 98-117.

Aristotle, De Anima (On the Soul), London 1987; Maurice Merleau-Ponty, Le visible et l'invisible, Paris 1964.

Rudolf Arnheim, Film as Art, Berkeley and Los Angeles 1957.

Béla Balázs, The Spirit of Film, in Béla Balázs: Early Film Theory, New York and Oxford 2010.

Roland Barthes, Camera Lucida: Reflections on Photography, New York 1981.

Stephanie Baumann, Im Vorraum der Geschichte: Siegfried Kracauers History: The Last Things Before the Last, Konstanz 2014.

Walter Benjamin, "On the Concept of History," 2005, https://www.marxists. org/reference/archive/benjamin/1940/history.htm (last accessed May 1, 2020).

Christa Blümlinger, Kino aus zweiter Hand: Zur Ästhetik materieller Aneignung im Film und in der Medienkunst, Berlin 2009.

Thiemo Breyer and Daniel Creutz, "Historische Erfahrung: Ein phänomenologisches Schichtenmodell," in Daniel Creutz (ed.), Erfahrung und Geschichte: Historische Sinnbildung im Pränarrativen, Berlin 2010, pp. 332-364.

Francesco Casetti, Communicative Negotiation in Cinema and Television, Milan 2002.

Michel Foucault, "Of Other Spaces: Utopias and Heterotopias," 1984, http:// web.mit.edu/allanmc/www/foucaultl.pdf (last accessed May 1, 2020).

Bernhard Groß, Die Filme sind unter uns: Zur Geschichtlichkeit des frühen deutschen Nachkriegskinos: Trümmer-, Genre-, Dokumentarfilm, Berlin 2015. 
Andreas Jacke, Traumpassagen: Eine Filmtheorie mit Walter Benjamin, Würzburg 2013.

Hermann Kappelhoff, The Politics and Poetics of Cinematic Realism, New York 2015. Siegfried Kracauer, Theory of Film: The Redemption of Physical Reality, Princeton 1997.

Siegfried Kracauer, History — the Last Things Before the Last, Princeton 1995.

Katharina Lindner, "Questions of embodied difference: Film and queer phenomenology," NECSUS, autumn 2012: “Tangibility,” https://necsus-ejms.org/ questions-of-embodied-difference-film-and-queer-phenomenology/ (last accessed May 1, 2020).

Niklas Luhmann, Art as a Social System, Stanford 2000.

Thomas Morsch, Medienästhetik des Films: Verkörperte Wahrnehmung und ästhetische Erfahrung im Kino, Munich and Paderborn 2011.

Thomas Morsch, "Filmische Erfahrung im Spannungsfeld zwischen Körper, Sinnlichkeit und Ästhetik," montage AV 19:1, 2010, pp. 55-77.

Sabine Nessel, Kino und Ereignis: Das Kinematografische zwischen Text und Körper, Berlin 2008.

Simon Rothöhler, Amateur der Weltgeschichte: Historiographische Praktiken im Kino der Gegenwart, Zurich 2011.

Jörn Rüsen, Historik: Theorie der Geschichtswissenschaft, Cologne 2013.

Jörn Rüsen, Zerbrechende Zeit: Über den Sinn der Geschichte, Cologne 2001.

Steven Shaviro, The Cinematic Body, Minneapolis 1993.

Vivian Sobchack, The Address of the Eye: A Phenomenology of Film Experience, Princeton 1992.

Jo Tollebeek and Tom Verschaffel, De vreugden van Houssaye: Apologie van de historische interesse, Amsterdam 1992, p. 18; Johan Huizinga, Verzamelde werken 2: Nederland, Haarlem 1950.

Anke Zechner, Die Sinne im Kino: Eine Theorie der Filmwahrnehmung, Frankfurt 2013.

\section{Filmography}

The Eclipse (L'Eclisse); dir. Michelangelo Antonioni; Italy, France 1962.

Ku'damm 56; dir. Sven Bohse; Germany 2016.

Sky without Stars (Himmel ohne Sterne); dir. Helmut Käutner; Federal Republic of Germany 1955.

Years of Hunger (Hungerjahre); dir. Jutta Brückner; Federal Republic of Germany 1980. 
Open Access This chapter is licensed under the terms of the Creative Commons Attribution 4.0 International License (http://creativecommons.org/licenses/ by $/ 4.0 /$ ), which permits use, sharing, adaptation, distribution and reproduction in any medium or format, as long as you give appropriate credit to the original author(s) and the source, provide a link to the Creative Commons licence and indicate if changes were made.

The images or other third party material in this chapter are included in the chapter's Creative Commons licence, unless indicated otherwise in a credit line to the material. If material is not included in the chapter's Creative Commons licence and your intended use is not permitted by statutory regulation or exceeds the permitted use, you will need to obtain permission directly from the copyright holder. 